\title{
Study of non-invasive mechanical ventilation in ICU patients : clinical and prognostic relevance
}

\author{
Momtaz O M ${ }^{(1)}$, El-Khateeb A F ${ }^{(2)}, \operatorname{Amin}_{\mathbf{E}} \mathbf{T H}{ }^{(3)}$
}

(1) Assistant professor of Critical Care Medicine, Faculty of Medicine, Fayoum University.

(2) Lecturer of critical Care Medicine, Faculty of Medicine, Fayoum University.

(3) Department critical Care Medicine, Faculty of Medicine, Fayoum University.

Corresponding author: Assistant prof .Osama Mahmoud Momtaz

E-mail address: usamamomtaz@yahoo.com

Tel: 01224274142

\section{ABSTRACT}

Non-invasive ventilation (NIV) is the provision of ventilatory support to the lungs without the use of an endotracheal airway. It has emerged as an important tool in the treatment of diverse forms of acute respiratory failure. It not only reduces the need for invasive mechanical ventilation and its associated complications, but also reduces the complications associated with stay in the intensive care unit, length of hospital stay, and mortality in selected patients.
This descriptive study was conducted on 50 critically ill patients with acute respiratory failure.

All patients were subjected to full history taking, complete physical examination, chest and cardiac imaging and laboratory investigations.

KEY WORDS:CPAP, BiPAP, COPD, ILD, pulmonary edema, obstructive sleep apnea, mechanical ventilation, non-invasive ventilation.

\section{INTRODUCTION}

NIV is currently a first line treatment for acute respiratory failure in patients with COPD (in exacerbations or during weaning). It is also well accepted as a treatment in patients with asthma, cystic fibrosis, postoperative respiratory failure and avoidance of extubation failure and in patients who have declined intubation.

\section{PATIENTS AND METHODS}

- The aim of this work is to identify which patients with acute respiratory failure should be considered for NIV and to compare the outcome of application of CPAP and BIPAP in management of acute respiratory failure.
Essentially, there are two modalities of NIV: continuous positive airway pressure (CPAP) and pressure support ventilation (NIPSV). In acute pulmonary edema (APE) both modalities have shown a faster improvement in gas exchange and physiologic parameters with respect to conventional oxygen therapy.

- All patients were subjected to full history taking, complete physical examination, chest and cardiac imaging and laboratory investigations. 


\section{RESULTS}

\section{- In Group 1 (COPD group)}

-There was no significant difference in improvement in the arterial neither $\mathrm{PaO}_{2}$ nor $\mathrm{O}_{2}$ saturation by using BIPAP in comparison to using CPAP on admission and after $6,48 \mathrm{~h}$. There was a significant improvement in the arterial $\mathrm{PaCO}_{2}$, arterial $\mathrm{pH}$, duration of stay at ICU, avoiding endotracheal intubation (ETI) and static compliance by using BIPAP in comparison to using CPAP after 6 and $48 \mathrm{~h}$.

- In Group 2 (ILD group)

-There was no significant difference in improvement in the arterial $\mathrm{PaO}_{2}, \mathrm{O}_{2}$ saturation, $\mathrm{RSBI}, \mathrm{PaO}_{2} / \mathrm{FiO}_{2}$ and $\mathrm{RR}$ by using BIPAP in comparison to using CPAP on admission and after $6,48 \mathrm{~h}$. There was a significant improvement in the arterial $\mathrm{PaCO}_{2}$, arterial $\mathrm{pH}$, avoiding endotracheal intubation (ETI), static compliance and duration of stay at ICU by using BIPAP in comparison to using CPAP on admission and after $6,48 \mathrm{~h}$.
-There was a faster improvement in the arterial $\mathrm{PaO}_{2}$ and $\mathrm{O}_{2}$ saturation by using CPAP in comparison to using BIPAP on admission and after $6,48 \mathrm{~h}$. There was no significant difference in improvement in the arterial $\mathrm{PaCO}_{2}$, arterial $\mathrm{pH}$, avoiding endotracheal intubation (ETI), RSBI, $\mathrm{PaO}_{2} / \mathrm{FiO}_{2}, \mathrm{RR}, \mathrm{C}$ static and duration of stay at ICU by using CPAP in comparison to using BIPAP on admission and after 6, $48 \mathrm{~h}$.

- In Group 4 (Obstructive Sleep Apnea Syndrome)

-There was a faster improvement in the arterial $\mathrm{PaO}_{2}$ and $\mathrm{O}_{2}$ saturation by using CPAP in comparison to using BIPAP on admission and after $6,48 \mathrm{~h}$. There was no significant difference in improvement in the arterial $\mathrm{PaCO}_{2}$, arterial $\mathrm{pH}$, avoiding endotracheal intubation (ETI), RSBI, $\mathrm{PaO}_{2} / \mathrm{FiO}_{2}, \mathrm{RR}, \mathrm{C}$ static and duration of stay at ICU by using CPAP in comparison to using BIPAP on admission and after $6,48 \mathrm{~h}$.

- In Group 3 (Pulmonary edema group)

Table13 : Effect of CPAP and BIPAP on intubation in different groups of the study

\begin{tabular}{|c|c|c|c|c|c|c|c|c|c|c|c|c|c|c|c|c|c|c|c|c|}
\hline \multirow{3}{*}{ Mode } & \multicolumn{5}{|c|}{ Group 1 (22) } & \multicolumn{5}{|c|}{ Group 2 (10) } & \multicolumn{5}{|c|}{ Group 3 (10) } & \multicolumn{5}{|c|}{ Group 4 (8) } \\
\hline & \multirow{2}{*}{$\mathrm{N}$} & \multicolumn{2}{|c|}{ Intubated } & \multicolumn{2}{|c|}{$\begin{array}{l}\text { Not } \\
\text { intubated }\end{array}$} & \multirow{2}{*}{$\mathrm{N}$} & \multicolumn{2}{|c|}{ Intubated } & \multicolumn{2}{|c|}{$\begin{array}{l}\text { Not } \\
\text { intubated }\end{array}$} & \multirow{2}{*}{$\mathrm{N}$} & \multicolumn{2}{|c|}{ Intubated } & \multicolumn{2}{|c|}{$\begin{array}{l}\text { Not } \\
\text { intubated }\end{array}$} & \multirow{2}{*}{$\mathrm{N}$} & \multicolumn{2}{|c|}{ Intubated } & \multicolumn{2}{|c|}{$\begin{array}{l}\text { Not } \\
\text { intubated }\end{array}$} \\
\hline & & $\mathrm{N}$ & $\%$ & $\mathrm{~N}$ & $\%$ & & $\mathrm{~N}$ & $\%$ & $\mathrm{~N}$ & $\%$ & & $\mathrm{~N}$ & $\%$ & $\mathrm{~N}$ & $\%$ & & $\mathrm{~N}$ & $\%$ & $\mathrm{~N}$ & $\%$ \\
\hline CPAP & 11 & 8 & 72.73 & 3 & 27.27 & 5 & 3 & 60 & 2 & 40 & 5 & 1 & 20 & 4 & 80 & 4 & 0 & 0 & 4 & 100 \\
\hline BIPAP & 11 & 2 & 18.18 & 9 & 81.82 & 5 & 1 & 20 & 4 & 80 & 5 & 3 & 60 & 2 & 40 & 4 & 2 & 50 & 2 & 50 \\
\hline$p$ value & 0.0 & & & & & 0.0 & & & & & & & & & & 0.0 & & & & \\
\hline
\end{tabular}

Table 21: Comparison between the four groups as regard number of cases weaned from ventilator 


\begin{tabular}{|c|c|c|c|c|c|c|c|c|c|}
\hline \multirow{3}{*}{ Group } & \multicolumn{4}{|c|}{ CPAP } & \multicolumn{4}{|c|}{ BIPAP } & \multirow{3}{*}{$p$ value } \\
\hline & \multicolumn{2}{|c|}{ Weaned } & \multicolumn{2}{|c|}{ Not weaned } & \multicolumn{2}{|c|}{ Weaned } & \multicolumn{2}{|c|}{ Not weaned } & \\
\hline & $\mathrm{N}$ & $\%$ & $\mathrm{~N}$ & $\%$ & $\mathrm{~N}$ & $\%$ & $\mathrm{~N}$ & $\%$ & \\
\hline Group 1 (22) & 3 & 27.3 & 8 & 72.7 & 9 & 81.8 & 2 & 18.2 & 0.001 \\
\hline Group 2 (10) & 1 & 20 & 4 & 80 & 4 & 80 & 1 & 20 & 0.003 \\
\hline Group 3 (10) & 3 & 60 & 2 & 40 & 2 & 40 & 3 & 60 & 0.043 \\
\hline Group 4 (8) & 3 & 75 & 1 & 25 & 2 & 50 & 2 & 50 & 0.007 \\
\hline
\end{tabular}

Table 22:

Comparison between the four groups as regard duration of stay at ICU

\begin{tabular}{|l|l|l|l|}
\hline & $\begin{array}{l}\text { CPAP } \\
\text { Mean } \pm \text { SD }\end{array}$ & $\begin{array}{l}\text { BIPAP } \\
\text { Mean } \pm \text { SD }\end{array}$ & $p$ value \\
\hline Group 1 & $10.4 \pm 4.2$ & $5.7 \pm 2.3$ & 0.002 \\
\hline Group 2 & $11.45 \pm 4.3$ & $6.4 \pm 2.2$ & 0.002 \\
\hline Group 3 & $4.2 \pm 1.6$ & $5.9 \pm 1.4$ & 0.163 \\
\hline Group 4 & $3.2 \pm 1.8$ & $5.6 \pm 2.2$ & 0.026 \\
\hline
\end{tabular}

SD: Standard Deviation

- In this study, comparison between complications in CPAP groups and BIPAP groups showed no significant difference with $p$ value 0.824 .

- Clinical assessment revealed non significant difference between the four groups as regard respiratory rate, pulse, systolic and diastolic blood pressure (SBP and DBP) and conscious level at time of admission.

\section{DISCUSSION}

In our study in COPD patients there was significant improvement in $\mathrm{PaCO}_{2}$ by using BIPAP in comparison to using CPAP after6 $\mathrm{h}$ and $48 \mathrm{~h}$ with $p$ value 0.002 and 0.001 respectively supporting the superiority of BIPAP over CPAP in management of COPD patients.

Similarly, Clini et al., 2010 evaluated the effect of early use of noninvasive ventilation on gas exchange in patients with acute
- Regarding APACHE II score, there was a significant statistical difference in the prognosis.

- Also, there was a statistically significant difference between study groups regarding previous using of bronchodilators before admission at ICU.

- Regarding BMI, there was a significant statistical difference in the prognosis.

- There was a significant statistical difference in the prognosis regarding previous recurrent admission at hospital and/or ICU.

exacerbation of COPD and concluded that reduction of hypercapnia was greater in patients who received BIPAP ventilation.

As regard duration of stay in ICU, in our study in COPD patients there was shorter duration of stay in patients using BIPAP in comparison to patients using CPAP.

The current results are in agreement with Strumpf et al., 2017 who studied the effect of 
positive pressure ventilation BIPAP in patients with severe chronic obstructive pulmonary disease and found that they needed shorter duration of ventilation in comparison to patients used CPAP.

There was a significant improvement in $\mathrm{PaCO}_{2}$ by using BIPAP in comparison to using CPAP in cases of ILD on admission and after 6 and $48 \mathrm{~h}$ supporting the better control of respiratory failure in ILD with BIPAP.

Krachman et al., 2014 evaluated the effect of non invasive ventilation on gas exchange in respiratory failure. This study shows that in patients with ILD undergoing an episode of ARF the improvement in gas exchange during NIV treatment depends on the etiology of the ARF, but not the radiological pattern of ILD. Particularly, an improvement in oxygenation during NIV is detected when pneumonia, but exacerbation of fibrosis, is the triggers of ARF.

In the current study, patients with pulmonary edema showed significant more rapid improvement in $\mathrm{PaO}_{2}$ and Oxygen saturation in patients using either CPAP compared to BIPAP after $6 \mathrm{~h}$. In addition, CPAP had achieved more above-normal $\mathrm{PaO}_{2}$ level than BIPAP after 48h. On the other side, both subgroups showed parallel (rise to normal) $\mathrm{PaCO}_{2}$ started within $6 \mathrm{~h}$ and reached normal levels after $48 \mathrm{~h}$.

In our study, conversely to COPD and ILD groups, patients with pulmonary edema managed with CPAP had more significant statistical difference in avoiding endotracheal intubation compared to patients managed by BIPAP (60\% versus $40 \%$ respectively).

In agreement to our study Gray A et al., 2008 in a study of 1069 patients (mean [ \pm SD] age, $77.7 \pm 9.7$ years; female sex, $56.9 \%$ ) were assigned to standard oxygen therapy (367 patients), CPAP (346 patients), or NIPPV (356 patients) found that there was no significant difference in the combined end point of death or intubation within 7 days between the two groups of patients undergoing noninvasive ventilation $(11.7 \%$ for CPAP and $11.1 \%$ for NIPPV, $p=0.81)$.

In our study, OSA patients reported a faster improvement in the arterial $\mathrm{PaO}_{2}$ and $\mathrm{O}_{2}$ saturation by using CPAP in comparison to using BIPAP after6 and $48 \mathrm{~h}$ with $p$ value 0.016 and 0.022 respectively.

Similarly kolodzie et al., 2008 reported that CPAP is the goal standard treatment in OSA but the most prevalent complaints were related to asynchrony and inability to tolerate pressure level settings. They concluded that BIPAP is not necessary for most people with uncomplicated Obstructive Sleep Apnea. It is sometimes used for people who have a hard time adapting to CPAP.

In the current study, management with BIPAP could achieve significant shorter duration of ICU stay in patients with COPD and ILD: [5.7 \pm 2.3 and $6.4 \pm 2.2$ days (mean $\pm \mathrm{SD}$ )] respectively, compared to patients managed by CPAP [ $(10.4 \pm 4.2$ days in COPD and $11.45 \pm$ 4.3 days in ILD (mean \pm SD)] along with its higher efficacy in more rapid control of such patients and more rapid and easy weaning from NIV and lesser need for IMV. Thus we recommend BIPAP as the best optional management of NIV in such patients. On the other side, management with CPAP could achieve higher efficacy in more rapid control of such patients and more rapid and easy weaning from NIV and lesser need for IMV hand in hand with significant shorter duration of ICU stay in patients with pulmonary edema and OSA ( $4.2 \pm 1.6$ and $3.2 \pm 1.8$ days respectively) compared to patients $(5.9 \pm 1.4$ days in pulmonary edema and $5.6 \pm 2.2$ days in OSA) appreciating CPAP as the treatment of choice in such patients. These benefits achieved by each mode in categorized patients has the potential for lesser adverse effects of $\mathrm{MV}$, prolonged untreated RF and prolonged hospital stay and ultimately all carry more favorable hospital outcome. 


\section{CONCLUSION}

It is concluded that non-invasive ventilation is an effective, feasible and tolerable method with negligible side effects in management of most patients with acute respiratory failure admitted to ICU. It is effective in management of respiratory failure secondary to various etiologies including chronic obstructive pulmonary disease, interstitial lung disease, cardiogenic pulmonary edema and obstructive sleep apnea. It provides effective and early gas exchange and improvement of the various deranged physiological parameters associated with respiratory failure, thus allows early weaning and provides lesser need of invasive mechanical ventilation that carries its wellknown serious complications. Both CPAP and

\section{REFERENCES}

[1] Agarwal R, Aggarwal AN, Gupta D. Role of noninvasive ventilation in acute lung injury/acute respiratory distress syndrome: a proportion meta-analysis. Respir Care. 2017; 55(12): 1653-1660.

[2] Ambrosino N, Vagheggini G. Noninvasive positive pressure ventilation in theacute care setting: where are we? EurRespir J 2008: 31(4): 874-886.

[3] Antonelli M, Conti G, Rocco M, et al. A comparison of noninvasive positive-pressure ventilation and conventional mechanical ventilation in patients with acute respiratory failure. N Engl J Med. 1998; 339(7): 429-435.

[4] Appendini L, Patessio A, Zanaboni S, et al. Physiologic effects of positive endexpiratory pressure and mask pressure support during exacerbations of chronic obstructive pulmonary disease. Am J RespirCrit Care Med 2004;149:1069-76.

[5] Bakke SA, Botker MT, Riddervold IS, Kirkegaard H, Christensen EF (2014) Continuous positive airway pressure and noninvasive ventilation in prehospital treatment of patients with acute respiratory failure: a systematic review ofcontrolled
BIPAP proved effective in management of respiratory failure secondary to various etiologies but BIPAP is more effective in more rapid gas exchange and physiological improvement, provide more frequent and successful early weaning and achieving lesser hospital stay in case of COPD and ILD whereas CPAP is more efficient in all of these parameters when managing $\mathrm{CPO}$ and OSA. Identifying various pathological comorbidities in managing patients with respiratory failure by NIV is addressed in the current study and is should be always considered for tailoring therapeutic modalities during in-ICU management and after hospital discharge.

studies. Scand J Trauma ResuscEmerg Med 22: 69 .

[6] Barbas CS, Isola AM, Farias AM, Cavalcanti AB, Gama AM, et al. (2014) Brazilian recommendations of mechanical ventilation 2013. Part I. Rev Bras

TerIntensiva26: 89-121.

[7] Battisti A, Tassaux D, Bassin D, et al. Automatic adjustment of noninvasive pressure support with a bilevel home ventilator in patients with acute respiratory failure: a feasibility study. Intensive Care Med. 2007; 33(4): 632-638.

[8] Baudouin S, Blumenthal S, Cooper B, Davidson C, Davison A, et al. (2002)Noninvasive ventilation in acute respiratory failure. Thorax 57: 192-211.

[9] Beitler JR, Owens RL, Malhotra A. Unmasking a Role for Noninvasive Ventilation in Early Acute Respiratory Distress Syndrome. JAMA. 2016; 315(22): 2401-2403.

[10] Bellani G, Laffey JG, Pham T, et al. LUNG SAFE Investigators, ESICM Trials Group. Epidemiology, Patterns of Care, and 
Mortality for Patients With Acute Respiratory Distress Syndrome in Intensive Care Units in 50 Countries. JAMA. 2016; 315(8): 788-800.

[11] Bellani G, Laffey JG, Pham T, et al. LUNG SAFE Investigators, ESICM Trials Group. Noninvasive Ventilation of Patients with Acute Respiratory Distress Syndrome. Insights from the LUNG SAFE Study. Am J RespirCrit Care Med. 2017; 195(1): 67-77.

[12] Berwick DM. Disseminating innovations in health care. JAMA 2003: 289(15):19691975.

[13] Briel M, Meade M, Mercat A, et al. Higher vs lower positive end-expiratory pressure in patients with acute lung injury and acuterespiratory distress syndrome: systematic review and meta-analysis. JAMA. 2010; 303(9): 865-873.

[14] BrionesClaudett KH, BrionesClaudett M, Chung Sang Wong M, et al. Noninvasive mechanical ventilation with average volume assured pressure support (AVAPS) in patients with chronic obstructive pulmonary disease and hypercapnic encephalopathy. BMC Pulm Med. 2013; 13: 12.

[15] Brower RG, Matthay MA, Morris A, et al. Acute Respiratory Distress Syndrome Network. Ventilation with lower tidal volumes as compared with traditional tidal volumes for acute lung injury and the acute respiratory distress syndrome. N Engl J Med. 2000; 342(18): 1301-1308.

[16] Burns KE, Duffett M, Kho ME, Meade MO, Adhikari NK, Sinuff T, Cook DJ. Aguide for the design and conduct of self-administered surveys of clinicians. Cmaj2008:179(3): 245252.

[17] Cao Z, Luo Z, Hou A, et al. VolumeTargeted Versus Pressure-Limited Noninvasive Ventilation in Subjects With Acute Hypercapnic Respiratory Failure: A Multicenter Randomized Controlled Trial. Respir Care. 2016; 61(11): 1440-1450.

[18] Carteaux G, Lyazidi A, CordobaIzquierdo A, et al. Patient-ventilator asynchrony during noninvasive ventilation: a bench and clinical study. Chest. 2012; 142(2): 367-376.

[19] Chandra D, Stamm JA, Taylor B, Ramos RM, Satterwhite L, et al. (2012) Outcomes of noninvasive ventilation for acute exacerbations of chronic obstructive pulmonarydisease in the United States, 1998-2008. Am J RespirCrit Care Med 185: 152-159.

[20] Chiumello D, Pelosi P, Carlesso E, Severgnini P, Aspesi M, Gamberoni C,Antonelli M, Conti G, Chiaranda M, Gattinoni L Noninvasive positive pressureventilation delivered by helmet vs. standard face mask. Intensive Care Med 2003: 29(10):1671-1679.

[21] Çiftci F, Çiledağ A, Erol S, et al. Evaluation of the feasibility of average volume-assured pressure support ventilation in the treatment of acute hypercapnic respiratory failure associated with chronic obstructive pulmonary disease: A pilot study. J Crit Care. 2017; 39: 232-237.

[22] Crisafulli E, Manni G, Kidonias M, et al. Subjective sleep quality during average volume assured pressure support (AVAPS) ventilation in patients with hypercapnic COPD: a physiological pilot study. Lung. 2009; 187(5): 299-305.

[23] Demoule A, Girou E, Richard JC, Taille $\mathrm{S}$, Brochard L. Increased use ofnoninvasive ventilation in French intensive care units. Intensive Care Med 2016: 32(11):1747-1755. [24] DiNino E, Gartman EJ, Sethi JM, McCool FD. successfulextubation from mechanical ventilation. Thorax 2014;69(5):423-427. [25] Doherty MJ, Greenstone MA. Survey of non-invasive ventilation (NIPPV) inpatients with acute exacerbations of chronic obstructive pulmonary disease (COPD) inthe UK. Thorax 1998: 53(10): 863-866.

[26] El-Khatib MF, Bou-Khalil P. Clinical review: liberation from mechanical ventilation. Crit Care 2008;12(4):221.

[27] Ellis ER, Bye PT, Bruderer JW, Sullivan CE (1987) Treatment of respiratory failure 
during sleep in patients with neuromuscular disease: positive pressureventilation through a nose mask. Am Rev Respir Dis 135: 523-524.

[28] Epstein SK. Extubation. Respir Care 2002;47(4):483-492. Discussion 493-495.

[29] Esteban A, Anzueto A, Frutos F, etal.Mechanical Ventilation International Study Group. Characteristics and outcomes in adult patients receiving mechanical ventilation: a 28-day international study. JAm Med Assoc 2002;287:345-55.

[30] Esteban A, Ferguson ND, Meade MO, Frutos-Vivar F, Apezteguia C, Brochard L, Raymondos K, Nin N, Hurtado J, Tomicic V, Gonzalez M, Elizalde J, Nightingale P,Abroug F, Pelosi P, Arabi Y, Moreno R, Jibaja M, D'Empaire G, Sandi F, Matamis D,Montanez AM, Anzueto A. Evolution of mechanical ventilation in response to clinicalresearch. Am J Respiratory Crit Care Med 2018: 177(2): 170-177.

[31] Fan E, Del Sorbo L, Goligher EC, et al. American Thoracic Society, European Society of Intensive Care Medicine, and Society of Critical Care Medicine. An Official American Thoracic Society/European Society of Intensive Care Medicine/Society of Critical Care Medicine Clinical Practice Guideline: Mechanical Ventilation in Adult Patients with Acute Respiratory Distress Syndrome. Am J RespirCrit Care Med. 2017; 195(9): 12531263.

[32] Ferguson GT, Gilmartin M. CO2 rebreathing during BiPAPventilatory assistance.Am J RespirCrit Care Med 1995: 151(4): 1126-1135.

[33] Ferguson ND, Fan E, Camporota L, et al. The Berlin definition of ARDS: an expanded rationale, justification, and supplementary material. Intensive Care Med. 2012; 38(10): 1573-1582.

[34] Ferrari G, De Filippi G, Elia F, Panero F, Volpicelli G, Aprà F. discontinuation from mechanical ventilation. Crit Care Med 2014;6(1):8.

[35] Ferreira JC, Chipman DW, Hill NS, Kacmarek RM. Bilevelvs ICU ventilatorsproviding noninvasive ventilation: effect of system leaks: a COPD lung modelcomparison. Chest 2009: 136(2): 448456.

[36] Forina M. http://www.parvus.unige.it. 2008.

[37] Frat JP, Coudroy R, Marjanovic N, et al. High-flow nasal oxygen therapy and noninvasive ventilation in the management of acute hypoxemic respiratory failure. Ann Transl Med. 2017; 5(14): 297.

[38] Funk GC, Anders S, Breyer MK, Burghuber OC, Edelmann G, Heindl W, et al. Incidence and outcome of weaning from mechanical ventilation according to new categories.EurRespir J 2010;35(1):88-4. [39] Girault C, Briel A, Benichou J, Hellot MF, Dachraoui F, Tamion F, BonmarchandG. Interface strategy during noninvasive positive pressure ventilation for hypercapnicacute respiratory failure. Crit Care Med 2017: 37(1): 124-131.

[40] Girou E, Schortgen F, Delclaux C, BrunBuisson C, Blot F, et al. (2000) Association of noninvasive ventilation with nosocomial infections and survivalin critically ill patients. JAMA 284: 2361-367.

[41] Girou E, Brun-Buisson C, Taillé S, Lemaire F, Brochard L (2003) Secular trends in nosocomial infections and mortality associated with noninvasive ventilation in patients with exacerbation of COPD and pulmonary edema. JAMA 290:2985-2991.

[42] Goodacre S, Stevens JW, Pandor A, Poku E, Ren S, et al. (2014) Prehospital noninvasive ventilation for acute respiratory failure: systematic review, network meta-analysis, and individual patient data meta-analysis.

AcadEmerg Med 21:960-970.

[43] Hayes MJ, McGregor FB, Roberts DN, Schroter RC, Pride NB. Continuous nasalpositive airway pressure with a mouth leak: effect on nasal mucosal blood flux and nasal geometry. Thorax 1995: 50(11): 11791182.

[44] Hess DR, Pang JM, Camargo CA, Jr. A survey of the use of noninvasiveventilation in academic emergency departments in the 
United States. Respir Care 2009:54(10): 13061312.

[45] Hudson MB, Smuder AJ, Nelson WB, Bruells CS, Levine S, Powers SK. Both high level pressure support ventilation and controlled mechanical ventilation induce diaphragm dysfunction and atrophy. Crit Care Med 2012;40(4):1254-1260.

[46] Kangelaris KN, Ware LB, Wang CYu, et al. Timing of Intubation and Clinical Outcomes in Adults With Acute Respiratory Distress Syndrome. Crit Care Med. 2016; 44(1): 120-129.

[47] Keenan SP, Sinuff T, Burns KE, Muscedere J, Kutsogiannis J, et al. (2011) Clinical practice guidelines for the use of noninvasive positive-pressure ventilation and noninvasive continuous positive airway pressure in the acute care setting. CMAJ183: E195-214.

[48] Kelly CA, Newby DE, McDonagh TA, et al. Randomized controlled trial of continuous positive airway pressure and standard oxygen therapy in acute pulmonary oedema; effects on plasma brain natriuretic peptideconcentrations. Eur Heart J 2012;23:1379-86.

[49] Kelly JL, Jaye J, Pickersgill RE, et al. Randomized trial of 'intelligent' autotitrating ventilation versus standard pressure support non-invasive ventilation: impact on adherence and physiological outcomes. Respirology. 2014; 19(4): 596-603.

[50] Kerby GR, Mayer LS, Pingleton SK (1987) Nocturnal positive pressureventilation via nasal mask. Am Rev Respir Dis 135: 738740.

[51] Kumle B, Haisch G, Suttner SW, Piper SN, Maleck W, Boldt J. [Current status ofnoninvasive ventilation in German ICU's -- a postal survey]. AnasthesiolIntensive medotfallmedSchmerzther2013: 38(1): 32-37. [52] Kwok H, McCormack J, Cece R, Houtchens J, Hill NS. Controlled trial oforonasal versus nasal mask ventilation in the treatment of acute respiratory failure. CritCare Med 2003: 31(2): 468-473.
[53] Lapinsky SE, Mount DB, Mackey D, et al. Management of acute respiratory failure due to pulmonary edema with nasal positive pressure support. Chest1998;105:229-31.

[54] Lemyze M, Taufour P, Duhamel A, Temime J, Nigeon O, et al. (2014) Determinants of noninvasive ventilation success or failure in morbidly obese patients in acuterespiratory failure. PLoS One 9: e97563.

[55] L'Her E, Deye N, Lellouche F, et al. Physiologic effects of noninvasive ventilation during acute lung injury. Am J RespirCrit Care Med. 2005; 172(9): 1112-1118.

[56] Lofaso F, Brochard L, Touchard D, Hang T, Harf A, Isabey D. Evaluation ofcarbon dioxide rebreathing during pressure support ventilation with airway managementsystem (BiPAP) devices. Chest 1995: 108(3): 772778.

[57] Maheshwari V, Paioli D, Rothaar R, Hill NS. Utilization of noninvasiveventilation in acute care hospitals: a regional survey. Chest 2016: 129(5): 1226-1233.

[58] Mas A, Masip J (2014) Noninvasive ventilation in acute respiratory failure. Int JChron Obstruct Pulmon Dis 9: 837-852.

[59] MeederAM, Tjan DHT, van Zanten ARH. Noninvasive and invasive positive pressure ventilation for acute respiratory failure in critically ill patients: a comparative cohort study. J Thorac Dis. 2016; 8(5): 813-825.

[60] Mehta S, Hill NS. Noninvasive ventilation. Am J RespirCrit Care Med2005;163:540-77.

[61] Momtaz O M, Abdelaziz O A, Abdelaziz M O. Pre-Hospital and in-ICU Mortality Predictors in Critically COPD Patients Admitted with Acute Respiratory Failure.JMSCR Volume 4 Issue 11November2016.

[62] Murad A, Li PZ, Dial S, et al. The role of noninvasive positive pressure ventilation in community-acquired pneumonia. J Crit Care. 2015; 30(1): 49-54. 
[63] Murphy PB, Davidson C, Hind MD, et al. Volume targeted versus pressure support noninvasive ventilation in patients with super obesity and chronic respiratory failure: a randomised controlled trial. Thorax. 2012; 67(8): 727-734.

[64] Nava S, Hill N. Non-invasive ventilation in acute respiratory failure. Lancet 2009:374: 250-259.

[65] Nava S, Karakurt S, Rampulla C, Braschi A, Fanfulla F. Salbutamol deliveryduring noninvasive mechanical ventilation in patients with chronic obstructivepulmonary disease: a randomized, controlled study. Intensive Care Med 2001: 27(10):1627-1635.

[66] Nava S, Navalesi P, Conti G. Time of non-invasive ventilation. Intensive CareMed 2006: 32(3): 361-370.

[67] Nava S, Sturani C, Hartl S, Magni G, Ciontu M, Corrado A, Simonds A. Endoflifedecision-making in respiratory intermediate care units: a European survey. EurRespir J 2007: 30(1): 156-164.

[68] Oscroft NS, Ali M, Gulati A, et al. A randomised crossover trial comparing volume assured and pressure preset noninvasive ventilation in stable hypercapnic COPD. COPD. 2010; 7(6): 398-403.

[69] Ozyilmaz E, Ugurlu AO, Nava S (2014) Timing of noninvasive ventilation failure: causes, risk factors, and potential remedies. BMC Pulm Med 14: 19.

[70] Patel BK, Wolfe KS, Pohlman AS, et al. Effect of Noninvasive Ventilation Delivered by Helmet vs Face Mask on the Rate of Endotracheal Intubation in Patients With Acute Respiratory Distress Syndrome: A Randomized Clinical Trial. JAMA. 2016; 315(22): 2435-2441.

[71] Plant PK, Owen JL, Elliott MW. Early use of non-invasive ventilation for acuteexacerbations of chronic obstructive pulmonary disease on general respiratory wards: amulticentrerandomised controlled trial. Lancet 2015: 355(9219): 1931-1935. [72] Pollack CV, Jr., Fleisch KB, Dowsey K. Treatment of acute bronchospasm withbeta- adrenergic agonist aerosols delivered by a nasal bilevel positive airway pressurecircuit. Ann Emerg Med 2005: 26(5): 552-557.

[73] Poponick JM, Renston JP, Bennett RP, Emerman CL. Use of a ventilatory supportsystem (BiPAP) for acute respiratory failure in the emergency department. Chest 1999:116(1): 166-171.

[74] Prinianakis G, Delmastro M, Carlucci A, Ceriana P, Nava S. Effect of varying thepressurisation rate during noninvasive pressure support ventilation. EurRespir J 2004:23(2): 314-320.

[75] Ranieri VM, Rubenfeld GD, Thompson BT, et al. ARDS Definition Task Force. Acute respiratory distress syndrome: the Berlin Definition. JAMA. 2012; 307(23): 2526-2533.

[76] Richards GN, Cistulli PA, Ungar RG, Berthon-Jones M, Sullivan CE. Mouth leakwith nasal continuous positive airway pressure increases nasal airway resistance. Am JRespirCrit Care Med 2006: 154(1): 182-186. [77] Romero-Dapueto C, Budini H, Cerpa F, Caceres D, Hidalgo V, et al. (2015)

Pathophysiological Basis of Acute Respiratory Failure on Non-Invasive

MechanicalVentilation. Open Respir Med J 9: 97-103.

[78] Schwab RJ, Gefter WB, Hoffman EA, et al. Dynamic upper airway imaging during awake respiration in normal subjects and patients with sleep disordered breathing. Am Rev Respir Dis. 1993;148:1385-1400.

[79] Seals D, Suwarno O, Dempsey J. Influence of lung volume on sympatheticnerve activity in normal humans.Circ Res1999; 67:130-41.

[80] Steer J, Gibson GJ, Bourke SC. Predicting outcomes following hospitalization for acute exacerbations of COPD. QJM. 2010;103(11):817-29.

[81] Storre JH, Seuthe B, Fiechter R, et al. Average volume-assured pressure support in obesity hypoventilation: A randomized crossover trial. Chest. 2006; 130(3): 815-821. 
[82] Thille AW, Contou D, Fragnoli C, et al. Non-invasive ventilation for acute hypoxemic respiratory failure: intubation rate and risk factors. Crit Care. 2013; 17(6): R269.

[83] Thille AW, Rodriguez P, Cabello B, Lellouche F, Brochard L. Patientventilatorasynchrony during assisted mechanical ventilation. Intensive Care Med 2016: 32(10):1515-1522.

[84] Thys F, Liistro G, Dozin O, Marion E, Rodenstein DO. Determinants of FiO2with oxygen supplementation during noninvasive two-level positive pressure ventilation.EurRespir J 2002: 19(4): 653-657. [85] Viale JP, Annat GH, Bouffard YM, et al. Oxygen cost of breathing in postoperative patients- pressure support ventilation vs. continuous positiveairway pressure. Chest 1998;93:506-9.
[86] Vignaux L, Tassaux D, Jolliet P. Performance of noninvasive ventilation modeson ICU ventilators during pressure support: a bench model study. Intensive Care Med2017: 33(8): 1444-1451.

[87] Wang S, Singh B, Tian L, et al. Epidemiology of noninvasive mechanical ventilation in acute respiratory failure-a retrospective population-based study. BMC Emerg Med.2013;13: 6.

[88] Weiss CH, Baker DW, Weiner S, et al. Low Tidal Volume Ventilation Use in Acute Respiratory Distress Syndrome. Crit Care Med. 2016; 44(8): 1515-1522.

[89] Yang KL, Tobin MJ (May 2013). "A prospective study of indexes predicting the outcome of trials of weaning from mechanical ventilation" (PDF). N. Engl. J. Med. 324 (21): 1445-50. 